\title{
EVALUASI UJI PROFISIENSI WEPAL 2015.1 PADA CUPLIKAN TANAH
}

\section{Woro Yatu Niken Syahfitri, Syukria Kurniawati, Natalia Adventini, Endah Damastuti, Diah Dwiana Lestiani dan Muhayatun}

\author{
Pusat Sains dan Teknologi Nuklir Terapan, BATAN \\ JL. Tamansari No. 71, Bandung, 40132 \\ Email: woro@batan.go.id \\ Diterima: 06-02-2018 \\ Diterima dalam bentuk revisi: 29-03-2018 \\ Disetujui: 10-07-2018
}

\begin{abstract}
ABSTRAK
EVALUASI UJI PROFISIENSI WEPAL 2015.1 PADA CUPLIKAN TANAH. Pengendalian kualitas prosedur analitik sangat penting untuk menghasilkan data analisis yang andal. Partisipasi dalam program uji profisiensi yang diselenggarakan oleh WEPAL (Wageningen Evaluating Programmes for Analytical Laboratories) 2015.1, merupakan salah satu proses penting untuk meningkatkan akurasi dan ketepatan teknik analisis yang digunakan di laboratorium serta dalam peningkatan pemanfaatan reaktor riset. Cuplikan ISE (International Soil Analytical Exchange) diiradiasi pada fasilitas rabbit system dan dianalisis menggunakan metode AAN (Analisis Aktivasi Neutron). Evaluasi kinerja metode dilakukan dengan uji akurasi dan Z-score. Unsur yang dilaporkan sebanyak 14 unsur yang meliputi Al, As, Ca, Co, Cr, Fe, K, Mg, Mn, Na, Sc, Ti, V dan Zn. Berdasarkan hasil analisis14 unsur yang dilaporkan, 57,1-78,6\% memuaskan dengan $|Z| \leq 2 ; 7,14-$ $21,4 \%$ dipertanyakan dengan $2<|Z|<3$ dan $21,4-35,7 \%$ tidak memuaskan dengan $|Z| \geq 3$. Pada hasil yang tidak memuaskan/outlier dilakukan tindakan perbaikan dan hasil analisis menunjukkan terdapat kesesuaian dengan nilai Z-score berkisar antara $-2<Z<2$. Secara umum, metode AAN baik untuk analisis multielemen matrik tanah dengan hasil analisis yang andal dan tingkat validitas yang baik.
\end{abstract}

Kata kunci : uji profisiensi, AAN, tanah.

\section{ABSTRACT}

EVALUATION OF 2015.1 WEPAL PROFICIENCY TEST IN SOIL. Quality control of analytical procedures is essential for generating reliable analytical data. Participation in the WEPAL (Wageningen Evaluating Programs for Analytical Laboratories) 2015.1 is an important process to improve accuracy and precision of analytical techniques used in laboratory and increasing research reactor utilization. ISE (International Soil Analytical Exchange) sample was irradiated at the rabbit system facility and analyzed using NAA (neutron activation analysis). Evaluation of method performance was carried out by accuracy test and Z-score calculation. As much as 14 elements were reported i.e.: Al, As, $\mathrm{Ca}, \mathrm{Co}, \mathrm{Cr}, \mathrm{Fe}, \mathrm{K}, \mathrm{Mg}, \mathrm{Mn}, \mathrm{Na}, \mathrm{Sc}, \mathrm{Ti}, \mathrm{V}$, and $\mathrm{Zn}$. Based on analysis result of 14 elements reported, $57.1-78.6 \%$ were satisfactory with $|Z| \leq 2 ; 7.14-21.4 \%$ were questionable with $2<|Z|<3$ and $21.4-35.7 \%$ were unsatisfactory with $|Z| \geq 3$. For unsatisfactory results/ outliers, corrective action was performed and the results of the analysis are in good agreement with the Zscore value ranging from $-2<Z<2$. In general, the NAA method is good for the analysis of soil matrices with reliable analysis results and good validity levels.

Key words: proficiency test, NAA, soil 


\section{PENDAHULUAN}

Permasalahan lingkungan akibat berbagai aktivitas industri dan transportasi semakin meningkat yang dapat menyebabkan pencemaran terhadap tanah sekitarnya (1). Pencemaran tanah mempengaruhi kualitas lingkungan yang menyebabkan kontaminan di tanah dan tanaman. Dalam kasus logam berat, diketahui bahwa baik kontak langsung dengan lingkungan yang tercemar dan konsumsi makanan yang terkontaminasi dapat menyebabkan masalah kesehatan (2). Hal ini disebabkan tanah memainkan peran penting. Salah satunya dalam menentukan komposisi makanan karena unsur hara maupun logam berat berpotensi untuk memasuki rantai makanan melalui penyerapan, transformasi dan bioakumulasi oleh tanaman (3).

Terkait dengan hal ini, analisis yang tepat sangat diperlukan untuk penyelesaian permasalahan lingkungan. Karakterisasi dan jenis sumber pencemar terhadap cuplikan tanah penting untuk dilakukan agar dapat diketahui secara pasti karakteristik cuplikan tanah tersebut sehingga dapat dijadikan dasar dalam melakukan tindakan preventif dan penanggulangannya (1).

Pemilihan metode untuk analisis unsur dalam cuplikan lingkungan harus memenuhi fitness for purpose yang meliputi quality assurance/QA dan quality control/QC. Uji profisiensi merupakan salah satu prosedur yang efektif untuk penjaminan mutu (QA) dan pemantauan kinerja di laboratorium pengujian (4).

Pengendalian kualitas prosedur analitik sangat penting untuk menghasilkan data analisis yang andal (5) dan terjamin validitasnya. Program uji profisiensi merupakan proses penting untuk meningkatkan akurasi dan ketepatan teknik analisis yang digunakan di laboratorium, serta digunakan untuk melakukan evaluasi kinerja laboratorium pengujian terhadap kriteria yang telah ditetapkan sesuai kompetensinya (6-8). Uji profisiensi juga banyak digunakan untuk mengevaluasi kompetensi analitis laboratorium dan bagian dari proses akreditasi (9), mengidentifikasi masalah, penginisiasi tindakan perbaikan yang diperlukan, menentukan unjuk kerja metode pengujian dan menetapkan nilai bahan acuan (reference materials) (6).

Pada uji profisiensi, material uji dan metode analisis yang digunakan sama. Dengan melakukan uji profisiensi dapat terlihat apakah hasil uji suatu laboratorium akurat dan memuaskan. Selain itu, uji profisiensi juga bermanfaat untuk menyediakan perangkat jaminan mutu laboratorium dalam membandingkan kinerja laboratorium terhadap laboratorium lain yang sejenis, sehingga dapat melakukan perbaikan jika ada ketidaksesuaian $(6,10)$.

Data hasil analisis laboratorium dikatakan berkualitas bila data tersebut memiliki ketepatan dan ketelitian yang tinggi serta untuk mengambil tindakan perbaikan yang tepat apabila ditemukan perbedaan antara performance actual dan standar (10).

Salah satu metode analisis yang banyak digunakan adalah analisis aktivasi neutron (AAN). Analisis ini berdasarkan reaksi nuklir antara neutron dan nukleus target, yaitu suatu teknik analisis nuklir yang sangat akurat dan sensitif, non-destruktif, tidak memerlukan preparasi cuplikan yang rumit serta dapat mengukur banyak unsur seperti aluminium, 
antimon, arsen, chromium, selenium dan banyak logam tanah jarang dapat dideteksi menggunakan AAN dengan ketepatan yang baik (11-14). Diketahui bahwa metode AAN adalah teknik yang handal untuk menentukan berbagai unsur yang berperan penting dalam kesehatan manusia (15).

Laboratorium AAN di BATAN Bandung telah mengimplementasikan sistem mutu berdasarkan ISO/IEC 17025:2005, dan telah mendapatkan akreditasi dari Komite Akreditasi Nasional. Untuk menjamin mutu hasil pengujian yang merupakan salah satu persyaratan dalam ISO/IEC 17025:2005, dilakukan uji profisiensi dan/atau uji banding antar laboratorium (12).

Pada kegiatan ini, laboratorium AAN di BATAN Bandung mengikuti program uji profisiensi yang diselenggarakan oleh WEPAL (Wageningen Evaluating Programmes for Analytical Laboratories). Kegiatan pengendalian mutu ini bertujuan agar data analisis unsur dalam cuplikan lingkungan dapat merupakan data yang akurat, dapat dipercaya dan memiliki kualitas yang baik sehingga dapat mendukung pencapaian kegiatan renstra BATAN dalam bidang lingkungan, meningkatkan kemampuan analisis unsur runutan serta meningkatkan kerjasama antar laboratorium di tingkat internasional.

\section{TATAKERJA}

\subsection{Bahan dan peralatan}

Bahan yang diperlukan adalah cuplikan uji profisiensi ISE, bahan acuan bersertifikat SRM NIST 2711a montana soil, air demineralisasi $\left(>18 \quad \mathrm{M} \Omega \quad \mathrm{cm}^{2}\right)$, standar campuran ICP E-Merck, standar titrisol EMerck dan vial polyethylene 0,3 ml.

Peralatan yang digunakan adalah spektrometer sinar gamma (Canberra, Australia) menggunakan detektor high purity germanium (HPGe) dengan efisiensi relatif $15-35 \%$ dan resolusi $1,9 \mathrm{keV}$ untuk 1332,5 keV puncak Co-60.

\subsection{Pembuatan larutan standar campuran}

Larutan standar tetes $\mathrm{Al}, \mathrm{As}, \mathrm{Ca}, \mathrm{Co}$, $\mathrm{Cr}, \mathrm{Fe}, \mathrm{K}, \mathrm{Mg}, \mathrm{Mn}, \mathrm{Na}, \mathrm{Sc}, \mathrm{Ti}, \mathrm{V}$ dan $\mathrm{Zn}$ dibuat masing-masing dengan bobot 21; 9,8; 101,2; 1,$0 ; 1,01 ; 59,9 ; 21 ; 21 ; 1,0 ; 20,98 ; 0,1 ; 10$; 1,$01 ; 10 \mu \mathrm{g}$ dari larutan standard ICP E-Merck dan standard titrisol E-Merck dimasukkan ke dalam vial polyethylene $0,3 \mathrm{ml}$, kemudian dikeringkan dan vial disegel dengan cara dipanaskan.

\subsection{Preparasi cuplikan dan SRM}

Cuplikan ISE yang didapat dari penyelenggara uji profisiensi WEPAL, dengan kode ISE PER 2015.1 samp 1, 2015.1 samp 2, 2015.1 samp 3, 2015.1 samp 4 dan SRM NIST 2711a montana soil, ditimbang sebanyak $25 \mathrm{mg}$ ke dalam vial polyethylene 0,3 $\mathrm{ml}$, kemudian disegel dengan cara dipanaskan untuk menutupnya. Cuplikan beserta SRM dan standar siap untuk diiradiasi. Cuplikan ISE, standar SRM dan standar campuran diiradiasi bersamaan menggunakan fasilitas reaktor Rabbit System di reaktor G.A. Siwabessy dengan fluks neutron $\sim 10^{13} \mathrm{n} . \mathrm{cm}^{-2} \cdot \mathrm{s}^{-1}$ dan daya $15 \mathrm{MW}$. Radionuklida yang digunakan, energi- $\gamma$ dan rincian lain dari analisis disajikan pada Tabel $1(4)$. 

Vol. 19, No. 2, Agustus 2018: 61-70

Tabel 1. Parameter nuklir dari semua unsur $(11,16,17)$.

\begin{tabular}{ccccc}
\hline Unsur & $\begin{array}{c}\text { Radio- } \\
\text { nuklida }\end{array}$ & $\begin{array}{c}\text { Waktu } \\
\text { Paruh }\end{array}$ & $\begin{array}{c}\text { Sinar-y } \\
(\mathrm{kev})\end{array}$ & $\begin{array}{c}\text { Waktu } \\
\text { Iradiasi }\end{array}$ \\
\hline $\mathrm{Al}$ & $\mathrm{Al}-28$ & 2,24 menit & 1778,9 & 1 menit \\
$\mathrm{Ca}$ & $\mathrm{Ca}-49$ & 8,7 menit & 3084,4 & 1 menit \\
$\mathrm{Mg}$ & $\mathrm{Mg}-27$ & 9,45 menit & 1014,4 & 1 menit \\
$\mathrm{Mn}$ & $\mathrm{Mn}-56$ & 2,58 hari & 846,7 & 1 menit \\
$\mathrm{Ti}$ & $\mathrm{Ti}-51$ & 5,8 menit & 320,4 & 1 menit \\
$\mathrm{V}$ & $\mathrm{V}-52$ & 3,76 menit & 1434,1 & 1 menit \\
$\mathrm{As}$ & As-76 & 26,3 jam & 559,1 & 15 menit \\
$\mathrm{K}$ & $\mathrm{K}-42$ & 12,36 jam & 1524,7 & 15 menit \\
$\mathrm{Na}$ & $\mathrm{Na}-24$ & 15,02 hari & 1368,6 & 15 menit \\
$\mathrm{Co}$ & $\mathrm{Co}-60$ & 5,271 tahun & 1332,50 & 2 jam \\
$\mathrm{Cr}$ & $\mathrm{Cr}-51$ & 27,704 hari & 320,08 & 2 jam \\
$\mathrm{Fe}$ & Fe-59 & 44,496 hari & 1099,25 & 2 jam \\
$\mathrm{Sc}$ & $\mathrm{Sc}-46$ & 83,3 hari & 889,3 & 2 jam \\
$\mathrm{Zn}$ & Zn-65 & 243,8 hari & 1115,52 & 2 jam \\
\hline
\end{tabular}

\subsection{Pengukuran unsur}

Pengukuran sinar gamma dilakukan dan dianalisis dengan spektrometer sinar gamma (Canberra, Australia) menggunakan detektor high purity germanium (HPGe) dengan efisiensi relatif $15-35 \%$ dan resolusi 1,9 keV untuk 1332,5 keV puncak Co-60. Analisis spektrum menggunakan perangkat lunak Genie-2000. Kalibrasi energi menggunakan standar campuran radionuklida Amerisium (Am-241) Cesium (Cs-137) dan Cobalt (Co-60). Pengukuran sinar-y dilakukan selama $\pm 100-200$; 1000 dan 2000-4000 detik, masing-masing untuk iradiasi pendek, menengah dan panjang (4).

\subsection{Evaluasi}

Kinerja laboratorium dievaluasi dengan membandingkan hasil yang dilaporkan oleh laboratorium terhadap nilai kesepakatan/ nilai acuan, dengan menggunakan Z-score sesuai dengan Pers. $1(6,18,19)$.

$$
Z-\text { score }=\frac{\left(X-X_{\text {mean }}\right)}{s_{d}}
$$

$\mathrm{X}$ adalah nilai hasil pengujian laboratorium, $X_{\text {mean }}$ rerata dari semua nilai dihitung dengan model NDA (Normal Distribution Approximation) dan $\mathrm{S}_{\mathrm{d}}$ adalah standar deviasi dihitung dengan model NDA. Penilaian laboratorium dengan parameter Z-score diintepretasikan sebagai berikut:

$|Z| \leq 2$ memuaskan

$2<|Z|<3$ diperingatkan (questionable, berarti hasil analisis belum termasuk tidak memuaskan, tetapi sudah dalam batas diperingatkan)

$|Z| \geq 3 \quad$ tidak memuaskan

\section{HASIL DAN PEMBAHASAN}

Cuplikan ISE uji profisiensi WEPAL terdiri dari empat macam cuplikan, yang ditunjukkan pada Tabel 2.

Tabel 2. Kode, tipe dan origin cuplikan uji profisiensi (19).

\begin{tabular}{|c|c|c|c|}
\hline $\begin{array}{c}\text { Kode } \\
\text { Cuplikan }\end{array}$ & $\begin{array}{l}\text { Cupli- } \\
\text { kan }\end{array}$ & Tipe & Origin \\
\hline $\begin{array}{c}\text { ISE PER } \\
2015.1 \\
\text { samp } 1\end{array}$ & 860 & sediment & $\begin{array}{c}\text { Kreekkraksluizen/ } \\
\text { Netherland }\end{array}$ \\
\hline $\begin{array}{c}\text { ISE PER } \\
2015.1 \\
\text { samp } 2\end{array}$ & 869 & Clay & $\begin{array}{l}\text { Zeewolde/ } \\
\text { Netherland }\end{array}$ \\
\hline $\begin{array}{c}\text { ISE PER } \\
2015.1 \\
\text { samp } 3\end{array}$ & 900 & $\begin{array}{c}\text { calcaneous } \\
\text { brown soil }\end{array}$ & $\begin{array}{c}\text { Zurich/ } \\
\text { Switzerland }\end{array}$ \\
\hline $\begin{array}{c}\text { ISE PER } \\
2015.1 \\
\text { samp } 4\end{array}$ & 989 & riverclay & $\begin{array}{l}\text { Waginengan/ } \\
\text { Netherland }\end{array}$ \\
\hline
\end{tabular}

Hasil yang diperoleh dari keempat tipe cuplikan dilaporkan oleh seluruh laboratorium peserta uji profisiensi. Keempat cuplikan 
dipreparasi dan dianalisis secara bersamaan dengan SRM dan standar. Performance laboratorium dievaluasi berdasarkan Z-score, dimana Z-score menunjukkan akurasi hasil pengujian. Hasil uji profisiensi cuplikan 1 (860) ditunjukkan pada Tabel 3.

Hasil evaluasi pengujian cuplikan dengan kode 860 (sediment) didapatkan data dengan kategori $|Z| \leq 2$ sebanyak $50 \%$ untuk unsur $\mathrm{V}$ (vanadium), Sc (scandium), Mn (mangan), $\mathrm{Fe}$ (besi), $\mathrm{Cr}$ (kromium), Co (kobalt) dan $\mathrm{Ca}$ (kalsium), menunjukkan hasil memuaskan, sedangkan unsur dengan kategori $2<|Z|<3$ sebanyak $14,3 \%$ untuk unsur Al (aluminium) dan As (arsen), menunjukkan hasil diperingatkan (questionable, berarti hasil analisis belum termasuk tidak memuaskan, tetapi sudah dalam batas diperingatkan). Unsur dengan kategori $|\mathrm{Z}| \geq 3$ sebesar $35,7 \%$ untuk unsur $\mathrm{K}$ (kalium), $\mathrm{Na}$ (natrium), $\mathrm{Mg}$ (magnesium), Ti (titanium) dan seng ( $\mathrm{Zn}$ ), menunjukkan hasil tidak memuaskan.

Pada pengujian cuplikan dengan kode
869 (clay) seperti ditunjukkan pada Tabel 4 didapatkan data dengan kategori $|\mathrm{Z}| \leq 2$ sebanyak $78,6 \%$ untuk unsur $\mathrm{Zn}, \mathrm{V}, \mathrm{Ti}, \mathrm{Sc}$, $\mathrm{Mn}, \mathrm{Mg}, \mathrm{Cr}, \mathrm{Co}, \mathrm{Ca}, \mathrm{As}$, dan $\mathrm{Al}$, menunjukkan hasil memuaskan, sedangkan unsur dengan kategori $|\mathrm{Z}| \geq 3$ sebesar $21,4 \%$ untuk unsur $\mathrm{Na}, \mathrm{K}$ dan $\mathrm{Fe}$, menunjukkan hasil tidak memuaskan.

Hasil evaluasi pengujian cuplikan dengan kode 900 (calcaneous brown soil) seperti ditunjukkan pada Tabel 5 didapatkan data dengan kategori $|Z| \leq 2$ sebanyak $64,3 \%$ untuk unsur $\mathrm{V}, \mathrm{Ti}, \mathrm{Mn}, \mathrm{Mg}, \mathrm{Cr}, \mathrm{Co}, \mathrm{Ca}$, As dan $\mathrm{Al}$, menunjukkan hasil memuaskan, sedangkan unsur dengan kategori $2<|\mathrm{Z}|<3$ sebanyak 7,14\% untuk unsur Sc, menunjukkan hasil diperingatkan (questionable, berarti hasil analisis belum termasuk tidak memuaskan, tetapi sudah dalam batas diperingatkan). Unsur dengan kategori $|Z| \geq 3$ sebesar $28,6 \%$ untuk unsur untuk unsur $\mathrm{Zn}, \mathrm{Na}, \mathrm{K}$ dan $\mathrm{Fe}$, menunjukkan hasil tidak memuaskan.

Tabel 3. Hasil uji profisiensi cuplikan dengan kode ISE PER 2015.1 samp 1.

\begin{tabular}{ccccccc}
\hline & Unsur & Unit & $\begin{array}{c}\text { Reported } \\
\text { Value }\end{array}$ & NDAmean & Sd & Z-score \\
\cline { 2 - 6 } Kode Cuplikan & $\mathrm{Zn}$ & $\mathrm{mg} / \mathrm{kg}$ & 485,0 & 391,3 & 24,30 & $3,86^{* *}$ \\
& $\mathrm{~V}$ & $\mathrm{mg} / \mathrm{kg}$ & 53,00 & 53,69 & 2,830 & $-0,24$ \\
& $\mathrm{Ti}$ & $\mathrm{mg} / \mathrm{kg}$ & 3324 & 2143 & 165,4 & 7,14 ** \\
& $\mathrm{Sc}$ & $\mathrm{mg} / \mathrm{kg}$ & 5,550 & 5,670 & 0,360 & $-0,33$ \\
& $\mathrm{Na}$ & $\mathrm{mg} / \mathrm{kg}$ & 7745 & 4675 & 339,1 & 9,05 ** \\
& $\mathrm{Mn}$ & $\mathrm{mg} / \mathrm{kg}$ & 307,0 & 287,1 & 23,94 & 0,83 \\
& $\mathrm{Mg}$ & $\mathrm{mg} / \mathrm{kg}$ & 9974 & 4746 & 503,6 & 10,4 ** \\
& $\mathrm{K}$ & $\mathrm{mg} / \mathrm{kg}$ & 22967 & 12828 & 660,9 & 15,3 ** \\
& $\mathrm{Fe}$ & $\mathrm{g} / \mathrm{kg}$ & 23,40 & 25,35 & 1,440 & $-1,35$ \\
$\mathrm{Cr}$ & $\mathrm{mg} / \mathrm{kg}$ & 69,00 & 70,79 & 7,280 & $-0,25$ \\
& $\mathrm{Co}$ & $\mathrm{mg} / \mathrm{kg}$ & 7,760 & 8,120 & 0,770 & $-0,47$ \\
& $\mathrm{Ca}$ & $\mathrm{g} / \mathrm{kg}$ & 37,30 & 37,70 & 2,150 & $-0,18$ \\
& $\mathrm{As}$ & $\mathrm{mg} / \mathrm{kg}$ & 22,40 & 17,58 & 1,860 & 2,59 * \\
& $\mathrm{Al}$ & $\mathrm{g} / \mathrm{kg}$ & 36,30 & 31,93 & 1,771 & 2,47 * \\
\hline Keterangan * * & & & & &
\end{tabular}


Tabel 4. Hasil uji profisiensi cuplikan dengan kode ISE PER 2015.1 samp 2.

\begin{tabular}{ccccccc}
\hline & Unsur & Unit & $\begin{array}{c}\text { Reported } \\
\text { Value }\end{array}$ & NDAmean & Sd & Z-score \\
\cline { 2 - 6 } Kode Cuplikan & $\mathrm{Zn}$ & $\mathrm{mg} / \mathrm{kg}$ & 93,20 & 91,89 & 6,280 & 0,21 \\
& $\mathrm{~V}$ & $\mathrm{mg} / \mathrm{kg}$ & 67,20 & 68,39 & 4,780 & $-0,25$ \\
& $\mathrm{Ti}$ & $\mathrm{mg} / \mathrm{kg}$ & 3223 & 3422 & 218,5 & $-0,91$ \\
& $\mathrm{Sc}$ & $\mathrm{mg} / \mathrm{kg}$ & 7,900 & 8,360 & 0,460 & $-1,00$ \\
& $\mathrm{Na}$ & $\mathrm{mg} / \mathrm{kg}$ & 8680 & 6044 & 290,1 & 9,09 ** \\
& $\mathrm{Mn}$ & $\mathrm{mg} / \mathrm{kg}$ & 550,0 & 531,9 & 31,21 & 0,58 \\
& $\mathrm{Mg}$ & $\mathrm{mg} / \mathrm{kg}$ & 8555 & 8594 & 436,0 & $-0,09$ \\
& $\mathrm{~K}$ & $\mathrm{mg} / \mathrm{kg}$ & 25028 & 16731 & 711,8 & 11,7 ** \\
& $\mathrm{Fe}$ & $\mathrm{g} / \mathrm{kg}$ & 21,90 & 25,08 & 1,040 & $-3,07$ ** \\
& $\mathrm{Cr}$ & $\mathrm{mg} / \mathrm{kg}$ & 83,00 & 79,09 & 8,740 & 0,45 \\
$\mathrm{Co}$ & $\mathrm{mg} / \mathrm{kg}$ & 7,920 & 8,560 & 0,600 & $-1,07$ \\
& $\mathrm{Ca}$ & $\mathrm{g} / \mathrm{kg}$ & 35,60 & 36,82 & 2,070 & $-0,59$ \\
& $\mathrm{As}$ & $\mathrm{mg} / \mathrm{kg}$ & 15,20 & 12,27 & 1,710 & 1,71 \\
$\mathrm{Al}$ & $\mathrm{g} / \mathrm{kg}$ & 42,90 & 47,30 & 2,780 & $-1,58$ \\
\hline Keterangan: ${ }^{*}=2<|\mathrm{Z}|<3 ;{ }^{* *}=|\mathrm{Z}| \geq 3$ & & & & &
\end{tabular}

Tabel 5. Hasil uji profisiensi cuplikan dengan kode ISE PER 2015.1 samp 3.

\begin{tabular}{ccccccc}
\hline & Unsur & Unit & $\begin{array}{c}\text { Reported } \\
\text { Value }\end{array}$ & NDAmean & Sd & Z-score \\
\cline { 2 - 6 } Kode Cuplikan & $\mathrm{Zn}$ & $\mathrm{mg} / \mathrm{kg}$ & 57,10 & 75,76 & 6,020 & $-3,10^{* *}$ \\
& $\mathrm{~V}$ & $\mathrm{mg} / \mathrm{kg}$ & 78,40 & 81,61 & 6,280 & $-0,51$ \\
& $\mathrm{Ti}$ & $\mathrm{mg} / \mathrm{kg}$ & 3215 & 3089 & 200,1 & 0,63 \\
& $\mathrm{Sc}$ & $\mathrm{mg} / \mathrm{kg}$ & 7,130 & 8,220 & 0,370 & $-2,91^{*}$ \\
& $\mathrm{Na}$ & $\mathrm{mg} / \mathrm{kg}$ & 9286 & 7099 & 388,4 & $5,63^{* *}$ \\
& $\mathrm{Mn}$ & $\mathrm{mg} / \mathrm{kg}$ & 1057 & 1076 & 46,98 & $-0,41$ \\
& $\mathrm{Mg}$ & $\mathrm{mg} / \mathrm{kg}$ & 10651 & 9851 & 798,0 & 1,00 \\
& $\mathrm{~K}$ & $\mathrm{mg} / \mathrm{kg}$ & 19682 & 14848 & 812,1 & 5,95 ** \\
& $\mathrm{Fe}$ & $\mathrm{g} / \mathrm{kg}$ & 20,50 & 24,40 & 1,150 & $-3,41^{* *}$ \\
& $\mathrm{Cr}$ & $\mathrm{mg} / \mathrm{kg}$ & 115,7 & 112,50 & 13,77 & 0,23 \\
$\mathrm{Co}$ & $\mathrm{mg} / \mathrm{kg}$ & 9,290 & 10,18 & 0,720 & $-1,24$ \\
& $\mathrm{Ca}$ & $\mathrm{g} / \mathrm{kg}$ & 13,60 & 12,05 & 0,900 & 1,72 \\
& $\mathrm{As}$ & $\mathrm{mg} / \mathrm{kg}$ & 12,90 & 11,69 & 1,420 & 0,85 \\
& $\mathrm{Al}$ & $\mathrm{g} / \mathrm{kg}$ & 46,40 & 46,38 & 2,240 & 0,01 \\
\hline Keterangan: ${ }^{*}=2<|\mathrm{Z}|<3 ;{ }^{* *}=|\mathrm{Z}| \geq 3$ & & & & &
\end{tabular}

Hasil evaluasi pengujian cuplikan dengan kode 989 (riverclay) seperti ditunjukkan pada Tabel 6 didapatkan data dengan kategori $|Z| \leq 2$ sebanyak $57,1 \%$ untuk unsur Zn, V, Sc, Mn, Fe, Cr, Co dan $\mathrm{Ca}$, menunjukkan hasil memuaskan, sedangkan unsur dengan kategori $2<|\mathrm{Z}|<3$ sebanyak 21,4\% untuk unsur Ti, As dan Al, menunjukkan hasil diperingatkan dan unsur dengan kategori $|\mathrm{Z}| \geq 3$ sebesar $21,4 \%$ untuk unsur $\mathrm{Na}, \mathrm{Mg}$ dan $\mathrm{K}$, menunjukkan hasil tidak memuaskan. Hasil evaluasi dari keempat cuplikan ISE ditunjukkan pada Gambar 1.

Pada Gambar 1. menunjukkan bahwa hasil uji profisiensi unsur di dalam cuplikan ISE dengan kategori memuaskan $|Z| \leq 2$ didapatkan hasil $>50 \%$ dari unsur yang 
Tabel 6. Hasil uji profisiensi cuplikan dengan kode ISE PER 2015.1 samp 4.

\begin{tabular}{|c|c|c|c|c|c|c|}
\hline \multirow{15}{*}{ Kode Cuplikan } & Unsur & Unit & $\begin{array}{c}\text { Reported } \\
\text { Value }\end{array}$ & NDAmean & Sd & Z-score \\
\hline & $\mathrm{Zn}$ & $\mathrm{mg} / \mathrm{kg}$ & 1101 & 1048 & 73,11 & 0,73 \\
\hline & V & $\mathrm{mg} / \mathrm{kg}$ & 121,5 & 101,4 & 10,71 & 1,88 \\
\hline & $\mathrm{Ti}$ & $\mathrm{mg} / \mathrm{kg}$ & 4748 & 4120 & 310,4 & 2,02 * \\
\hline & Sc & $\mathrm{mg} / \mathrm{kg}$ & 10,73 & 11,44 & 0,600 & $-1,17$ \\
\hline & $\mathrm{Na}$ & $\mathrm{mg} / \mathrm{kg}$ & 5536 & 4498 & 262,4 & $3,96^{* *}$ \\
\hline & $\mathrm{Mn}$ & $\mathrm{mg} / \mathrm{kg}$ & 1238 & 1114 & 80,17 & 1,54 \\
\hline & $\mathrm{Mg}$ & $\mathrm{mg} / \mathrm{kg}$ & 17998 & 11143 & 1037 & 6,61 ** \\
\hline & K & $\mathrm{mg} / \mathrm{kg}$ & 25590 & 20392 & 1231 & 4,22 ** \\
\hline & $\mathrm{Fe}$ & $\mathrm{g} / \mathrm{kg}$ & 36,30 & 39,89 & 1,820 & $-1,98$ \\
\hline & $\mathrm{Cr}$ & $\mathrm{mg} / \mathrm{kg}$ & 274,7 & 274,2 & 26,08 & 0,02 \\
\hline & Co & $\mathrm{mg} / \mathrm{kg}$ & 20,76 & 21,65 & 1,480 & $-0,6$ \\
\hline & $\mathrm{Ca}$ & $\mathrm{g} / \mathrm{kg}$ & 41,90 & 38,19 & 2,280 & 1,63 \\
\hline & As & $\mathrm{mg} / \mathrm{kg}$ & 53,70 & 46,09 & 3,580 & 2,13 * \\
\hline & $\mathrm{Al}$ & $\mathrm{g} / \mathrm{kg}$ & 71,00 & 62,44 & 4,168 & 2,05 * \\
\hline
\end{tabular}

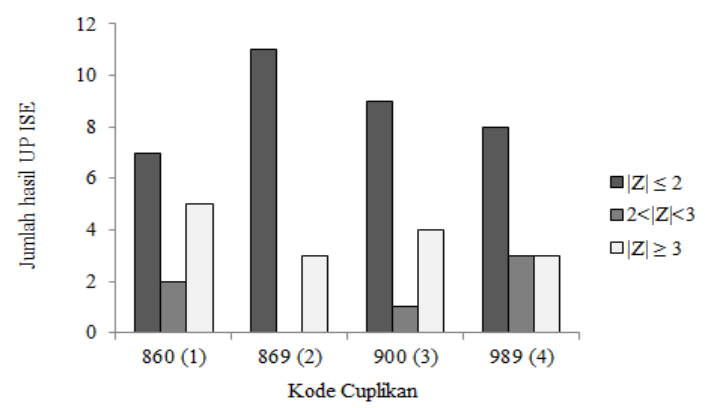

Gambar 1. Penilaian uji profisiensi WEPAL ISE hasil Laboratorium AAN yang diperoleh untuk putaran 2015.1.

dilaporkan sebanyak 14 unsur pada masingmasing keempat cuplikan. Berdasarkan hasil evaluasi dari keempat cuplikan ISE uji profisiensi WEPAL 2015.1, didapatkan nilai $Z$-score dengan kategori memuaskan 57,1$78,6 \%$ unsur yang dilaporkan laboratorium, dengan nilai Z-score kategori diperingatkan sebesar 7,14-21,4\% (diberi lambang $\$ /^{*}$ ) dan unsur dengan Z-score kategori tidak memuaskan sebesar 21,4-35,7\% (diberi lambang $\left.\$ \${ }^{* *}\right)$. Hasil uji profisiensi 2015.1 dengan nilai Z-score kategori tidak memuaskan didapatkan sebesar 21.4$35.75 \%$ dalam hal ini tidak dipengaruhi oleh homogenitas cuplikan, melainkan dipengaruhi oleh proses selama preparasi hingga analisis dan pengolahan data.

Sesuai dengan kebijakan KAN (Komite Akreditasi Nasional), hasil yang tidak memuaskan harus dilakukan tindakan perbaikan dengan periode tertentu. Setelah dilakukan kaji ulang hasil analisis, menunjukkan bahwa ada beberapa unsur waktu paruh pendek mendapatkan hasil tidak memuaskan. Kondisi ini menunjukkan bahwa untuk analisis analit dengan waktu paruh pendek, sumber kesalahan dalam pengujian dapat bersifat acak maupun sistematik. Kedepan perlu diperhatikan untuk analisis analit dengan waktu paruh pendek diantaranya massa cuplikan tidak boleh terlalu banyak dan lama aktivasi harus tepat karena berkaitan dengan paparan radiasi cuplikan pasca iradiasi. Apabila 


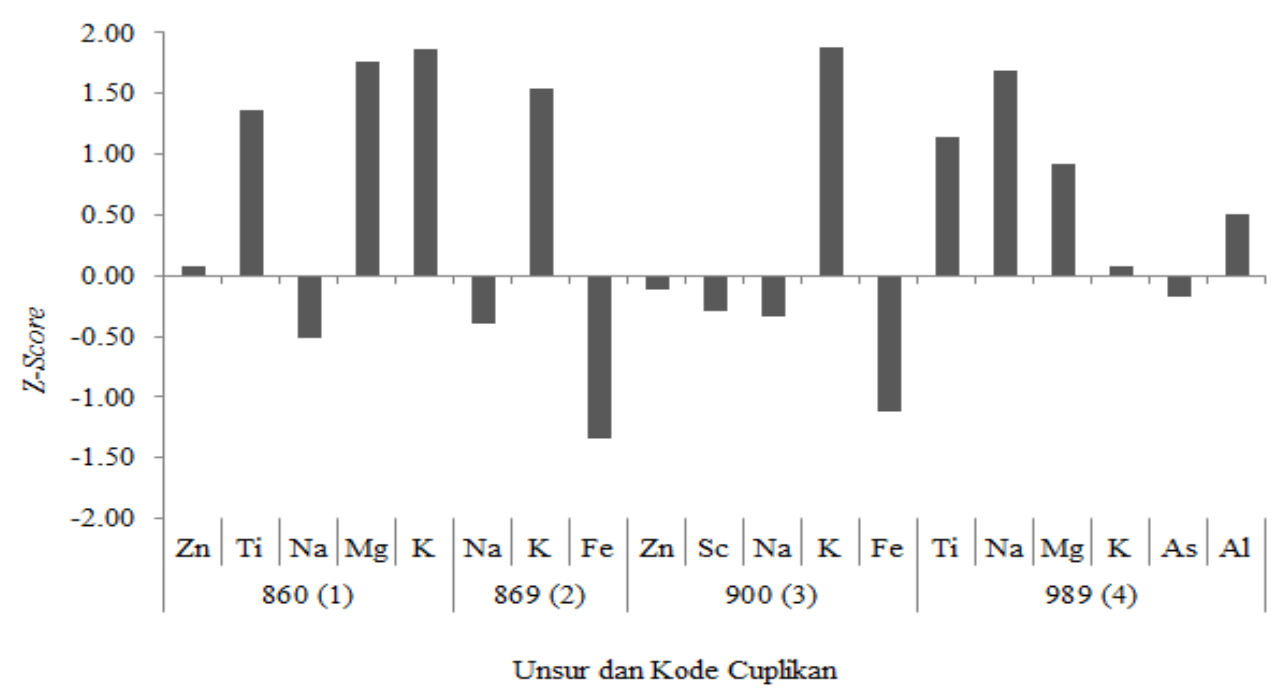

Gambar 2. Hasil tindakan perbaikan cuplikan ISE 2015.1

paparan iradiasi terlalu tinggi, maka cuplikan harus didelay karena dead time pada saat pencacahan $>10 \%$, kondisi ini menyebabkan sering kehilangan analit tertentu karena sudah habis meluruh ataupun hasil pencacahan tidak sebanding antara sampel dan standar. Ada beberapa unsur dengan waktu paruh sedang dan panjang tidak masuk kriteria Z-score. Hal ini disebabkan adanya interferensi dengan analit lain (6). Sebagai contoh unsur $\mathrm{Zn}$, dan diketahui penyebab kesalahan ada pada spektrum hasil pencacahan. Energi gamma Zn-65 adalah $1115,5 \mathrm{keV}$. Spektrum dari unsur $\mathrm{Zn}$ tumpang tindih dengan Eu-152 pada energi 1112,07 keV dan Sc-46 pada energi $1120,51 \mathrm{keV}$. Adanya spektrum pengganggu tersebut menyebabkan penentuan region of interest (ROI) menjadi tidak optimal sehingga mempengaruhi perhitungan kadar unsur $\mathrm{Zn}$ (12) dan $\mathrm{Na}-24$ dengan energi gamma 1368,6 keV berinterferensi dengan Sb-124 pada energi gamma 1368,2 keV (6). Selain itu, outlier disebabkan penggunaan SRM sebagai pembanding standar komparatif saat pengolahan data, dimana 68
SRM tersebut mempunyai matrik yang kurang sesuai dengan cuplikan. Setelah dilakukan analisis spektrum dan pengolahan data kembali dengan penghitungan komparatif terhadap standar tetes, hasil analisis cuplikan menunjukkan terdapat kesesuaian dengan nilai Z-score berkisar antara $-2<Z<2$, seperti ditunjukkan pada Gambar 2. Secara umum, metode AAN baik untuk analisis multielemen matrik tanah dengan hasil analisis yang andal dan tingkat validitas yang baik.

\section{KESIMPULAN}

Kegiatan uji profisiensi WEPAL 2015.1 dapat mengetahui performance Laboratorium AAN PSTNT dalam pengujian analit dalam sampel matrik tanah. Dari 14 unsur hasil yang dilaporkan 57,1-78,6\% memiliki nilai Z-score berkisar $|Z| \leq 2$, sedangkan 7,14-21,4\% memiliki nilai Zscore $2<|Z|<3$ dan $21,4-35,7 \%$ memiliki nilai $Z$-score $|Z| \geq 3$. Hasil yang tidak memuaskan/outlier dilakukan tindakan perbaikan dan diperoleh nilai Z-score untuk unsur-unsur tersebut berkisar pada $-2<Z<2$. 
Secara umum, metode AAN baik untuk analisis multielemen matrik tanah dengan hasil analisis dan tingkat validitas yang baik.

\section{UCAPAN TERIMAKASIH}

Penulis mengucapkan terimakasih kepada Pusat Sains dan Teknologi Nuklir Terapan BATAN yang telah memberikan dukungan dalam pelaksaan kegiatan ini, serta seluruh personel yang telah membantu dalam kegiatan uji profisiensi ini.

\section{DAFTAR PUSTAKA}

1 Lestiani D. D., Muhayatun and Adventini N. Aplikasi teknik analisis aktivasi neutron pada karakterisasi sampel SRM lingkungan. Indo J. Chem 2009; 9(2):231-235. https://doi.org/10.22146/ijc.21535

2 Bilo F., Borgese L., Zacco A., Lazo P., Zoani C., Zappa G., Bontempi E., and Depero El. Total Reflection X-Ray Fluorescence Spectroscopy to Evaluate Heavy Metals Accumulation in Legumes. J Anal Bioanal Tech 2015; 7(1):1-7. http://dx.doi.org/10.4172/21559872.1000292

3 Tóth G., Hermann T., Da Silva M. R., And Montanarella L. Heavy metal in agricultural soil of the European union with implications for food safety. Environ. Int. 2016; 88:299-309. http://dx.doi.org/10.1016/j.envint.2015.1 2.01

4 Kurniawati S., Lestiani D. D., Adventini N., Kusmartini I., and Syahfitri WYN. Karakterisasi sampel uji banding matriks lingkungan. Prosiding Seminar Nasional
Sains dan Teknologi Nuklir. Bandung: Penerbit PSTNT BATAN; 2015.

5 Dijk Dirkje Van And Houba Victor JG. Wageningen evaluating programmes for analytical laboratories (Wepal). Arh hig rada toksikol 1999; 50(1):31-36 https://hrcak.srce.hr/file/5154

6 Mulyaningsih TH. Rina. Uji Profisiensi Sampel Matrik Tanah Dan Sedimen Sungai Dalam Rangka Pengendalian Mutu Hasil Pengujian Laboratorium. Prosiding Seminar Nasional TAN. Yogyakarta: Penerbit PTAPB BATAN; 2013.

7 Hamidatou L., Slamene H., Zouranen B., Beagaa S., Messaoudi M., And Kamel D. External quality assessment of Algerian neutron activation analysis laboratory approaches. International Journal of Engineering Research And Management (IJERM) 2016; 3(07):1218. http://www.ijerm.com

8 Kurniawati S., Kusmartini I., Lestiani DD., Dan Syahfitri WYN. Uji interkomparasi metode AAN dan XRF untuk analisis sampel sedimen IAEA. Jurnal IPTEK Nuklir Ganendra 2014; 17(1):27-33. http://dx.doi.org/10.17146/gnd.2014.17.1 .1298

9 Handayani EM., Komalasari I dan Ketrin R. Determination of assigned values for cadmium, cobalt and manganese in drinking water proficiency testing. Procedia Chemistry 2015; 16:72-77. doi: 10.1016/j.proche.2015.12.025

10 Damastuti E., Adventini N. and Lestiani DD. Pengendalian Mutu Analisis Unsur Dalam Bahan Pangan Menggunakan Analisis Aktivasi Neutron. Prosiding 
Seminar Nasional Sains dan teknologi Nuklir. Bandung: Penerbit PTNBR

BATAN; 2011.

11 IAEA. Sampling and analytical methodologies for instrumental neutron activation analysis of airborn particulate matter (Series No.4). IAEA; 1992.

12 Kurniawati S., Lestiani DD., Adventini N. Karakterisasi unsur dalam sampel tanah dan sedimen menggunakan teknik AAN untuk uji banding laboratorium Batan. Prosiding Seminar Nasional Sains dan Teknologi Nuklir. Bandung: Penerbit PTNBR BATAN; 2009.

13 Naeem H. S., Khaniabadi P. M., and Eid E. M. A comparison between neutron activation analysis and $x$-ray fluorescence methods in analyzing the granite samples. J. Chem. Chem. Eng. 2013; 7:803-807.

https://www.researchgate.net/publication /257945321

14 Hailu A. T., Chaubey A. K., Mamo D. A., And Hibstie A. Y. Application of instrumental neutron activation analysis for the elemental analysis of various rocks from areas around debre birhan city, Ethiopia. IJRRAS. [serial online] 2012 July [cited 2017 July 7]; 12(1): [11 screens]. Available from:

[www.arpapress.com/Volumes/Vol12lss ue1/IJRRAS_12_1_15.pdf ].

15 Kongsri S., Srinuttrakul W., Sola P., and Busamongkol A. Instrumental neutron activation analysis of selected elements in Thai jasmine rice. Procedia 2016; 89: 361-365. doi: 10.1016/j.egypro.2016.05.047
16 Laoharojanaphand S., Busamongkol A., Permnamtip V., Judprasong K., And Chatt A. A pilot study to measure level of selected elements in Thai foods by instrumental neutron activation analysis. J Radioanal Nucl Chem 2012; 294: 323327.

DOI 10.1007/s10967-012-1884-X

17 Samad El MA., Hanafi HA. Analysis of toxic heavy metal in cigarettes by instrumental neutron activation analysis. Journal of Taibah University for Science 2017; 11: 822-829. http://dx.doi.org/10.1016/j.jtusci.2017.01. 007

18 Hamim N, Sujarwo, Hindayani A, Elishian C, and Juas Oman. Proficiency testing and laboratory performance in the field of $\mathrm{pH}$ measurment: an Indonesian experiment. Procedia Chemistry 2015; 16: 648-655. doi: 10.1016/j.proche.2015.12.004

19 WEPAL. Annual report 2015 ISE (International Soil Analytical Exchange). Netherland: Wageningen University Environmental Science; 2016. 